\title{
Peningkatan Pengetahuan Ibu Hamil tentang ANC di Era New Normal
}

\author{
Farida Yuliani, Erfiani Mail, Fitria Edni Wari \\ Email: faridayuliani001@gmail.com \\ STIKES Majapahit Mojokerto, Indonesia \\ Jl. Raya Gayaman KM 02 Mojoanyar Mojokerto \\ Telp. 081236454098
}

\begin{abstract}
Abstrak
Kegiatan pengabdian kepada masyarakat ini bertujuan meningkatkan pengetahuan ibu hamil tentang Ante Natal Care (ANC) di era new normal di Desa Gayaman Kecamatan Mojoanyar. Metode yang digunakan adalah ceramah dan alat ukur yang dipakai adalah kuesioner. Materi yang diberikan pada ibu hamil adalah tentang Ante Natal Care (ANC). Kegiatan ini diikuti oleh 31 ibu hamil di Desa Gayaman Kecamatan Mojoanyar pada bulan Maret 2021- Juli 2021.Hasil yang didapatkan yaitu $100 \%$ peserta memiliki pengetahuan yang baik tentang pengetahuan ibu hamil tentang ANC di masa pandemi ini. Hendaknya ibu hamil dan tenaga kesehatan tetap menjaga protokol kesehatan dengan ketat selama pemeriksaan ANC dimasa pandemic ini agar terhindar dari bahaya covid 19 .
\end{abstract}

Kata kunci: ante natal care; ibu hamil

\begin{abstract}
This community service activity aims to increase the knowledge of pregnant women about Ante Natal Care (ANC) in the new normal era in Gayaman Village, Mojoanyar District. The method used is a lecture and the measuring instrument used is a questionnaire. The material given to pregnant women is about Ante Natal Care (ANC). This activity was attended by 31 pregnant women in Gayaman Village, Mojoanyar District in March 2021-July 2021. The results obtained were $100 \%$ of the participants had good knowledge about knowledge of pregnant women about ANC during this pandemic. Pregnant women and health workers should strictly maintain health protocols during ANC checks during this pandemic to avoid the dangers of covid 19.
\end{abstract}

Keywords: ante natal care; pregnant mom 


\section{Pendahuluan}

Ante natal care merupakan pemeriksaan kehamilan yang bertujuan untuk meningkatkan kesehatan fisik dan mental pada ibu hamil secara optimal, sehingga mampu menghadapi masa persalinan, nifas, persiapan pemberian ASI secara ekslusif, serta kembalinya kesehatan alat reproduksi dengan wajar(1).

Penggunaan pelayanan kesehatan maternal merupakan pendekatan yang efektif untuk mengurangi risiko mortalitas dan morbiditas maternal. Melakukan kunjungan ke klinik antenatal dan bersalin dengan bantuan tenaga kesehatan terlatih dapat menurunkan morbiditas dan mortalitas melalui deteksi dini dan manajemen komplikasi(2).

Pengetahuan adalah hasil penginderaan manusia atau hasil seseorang terhadap objek melalui indera yang dimiliki (mata, hidung, telinga dan sebagainya) (3).

Era new normal mengharuskan seluruh lapisan masyarakat untuk berdamai dan hidup berdampingan dengan Covid-19. Dalam new normal, beberapa sektor kegiatan telah dibuka untuk kembali menggerakan roda perekonomian negara. Tapi tak serta merta penyebaran virus ini mereda, malah bisa lebih meningkat(4).

Potensi untuk meningkatkan kembali kasus Covid-19 masih sangat tinggi, banyak sekarang kasus-kasus baru bermunculan di tempat kerja atau perkantoran, oleh sebab itu, dibutuhkan kesiapsiagaan dan kesadaran seluruh lapisan masyarakat untuk tetap menjalankan protokol kesehatan. Hal ini menjadi tantangan besar bagi tenaga kesehatan untuk terus membantu seluruh masyarakat dalam melakukan pencegahan Covid-19(4).
Sementara itu, tak hanya bagi perawat, bidan juga memiliki peran penting dan standar khusus selama melakukan pelayanan di era new normal(5). Menurut Sri Dinengsih, S.ST. M.Kes. mengatakan, semua tempat persalinan harus siaga Covid-19 dan standar APD minimal level 2(4).

"Kesehatan dan keselamatan ibu dan janin juga harus diperhatikan oleh bidan. Pemeriksaan kehamilan atau Antenatal care (ANC) juga harus dilakukan dengan standar Covid-19 baik di tempat mandiri praktik bidan atau fasilitas kesehatan," jelas praktisi kebidanan itu. Dini menambahkan, tak hanya bagi bidan, ibu hamil juga perlu aktif mencari informasi mengenai standar ANC atau persalinan selama new normal. Selain itu juga membaca buku tentang 'kesehatan ibu dan anak atau KIA dan menerapkannya dalam kehidupan sehari-hari. "Nantinya, dengan mengikuti prosedur Covid-19, ibu hamil bisa meminimalisir bahaya atau risiko dengan mengikuti panduan deteksi dini Covid-19. Jika sudah ada tanda saat kehamilan maka bisa dilakukan pencegahan dan pengobatan," Para bidan untuk terus melakukan edukasi terhadap pasien, keluarga, dan masyarakat agar bisa beradaptasi dengan era new normal dan selalu menerapkan protokol kesehatan saat kunjungan(4).

Peran para tenaga kesehatan juga tidak terlepas dari keikutsertaan generasi muda untuk mencegah Covid-19. "Generasi muda khususnya mahasiswa juga memiliki peran dalam era new normal. Di samping mentaati protokol kesehatan, mereka juga bisa berkontribusi langsung menjadi relawan atau aktivis sosial, dan memberikan pemahaman pada masyarakat tentang virus corona," 
Selain itu, mahasiswa harus tetap menjaga peralatan pribadi untuk selalu higienis, serta tidak melakukan perkumpulan tanpa menerapkan protokol kesehatan. Mahasiswa juga perlu memerhatikan kondisi fisiknya seperti menjaga imun dan mengatur manajemen stress(4).

Masyarakat sebagai garda terdepan dalam pencegahan Covid19 perlu adanya pendampingan dari orang yang memiliki kompetensi di bidang kesehatan. Oleh sebab itu, penting dilakukan sharing ilmu pengetahuan dan informasi selama masa Covid-19. "Ini adalah masa yang sangat berat buat kita semua. Maka dari itu kita perlu sadar diri untuk terus mengikuti aturan yang dianjurkan untuk mengurangi penyebaran Covid-19. Memasuki new normal bukan berarti kita lengah untuk menjaga kesehatan, justru kita harus lebih ekstra dalam menjalankan protokol kesehatan"(4).

Tujuan Umum meningkatkan pengetahuan, adanya perubahan perilaku mengenai persepsi dan perilaku dalam pemeriksaan ANC.Tujuan Khusus meningkatkan interaksi antar ibu hamil dengan petugas kesehatan sehingga mampu berbagi pengalaman dalam pemeriksaan ANC, meningkatkan pemahaman dan perilaku wanita usia subur tentang pemeriksaan ANC.

\section{Metode}

Survei lapangan bertujuan untuk mengamati situasi dan keadaan desa yang direncanakan sebagai objek sasaran.

Sasaran program ini adalah semua ibu hamil yang ada di dusun Tambak rejo dan Gayaman di Desa Gayaman yang berjumlah 31 orang dengan diberikan kuesioner pre dan post kegiatan pelaksanaan. Kuesioner berjumlah 10 soal mengenai bagaimana ANC dilakukan selama masa new normal di masa pandemi ini.

Berkoordinasi dengan warga masyarakat, kader desa, serta kepala desa untuk menentukan kesepakatanmufakat antara pelaksanaan program dengan masyarakat dan pihak desa.

Sosialisasi program bertujuan untuk memberikan informasi mengenai rencana serangkaian pelaksanaan program yang disampaikan kepada kader, dan kepala desa.

\section{Hasil dan Pembahasan}

Diagram dibawah ini merupakan hasil pre dan post test pengetahuan ibu hamil mengenai pengetahuan para ibu hamil tentang Ante Natal Care (ANC) di era new normal.

Diagram 3. Hasil Pretest dan Post Tes

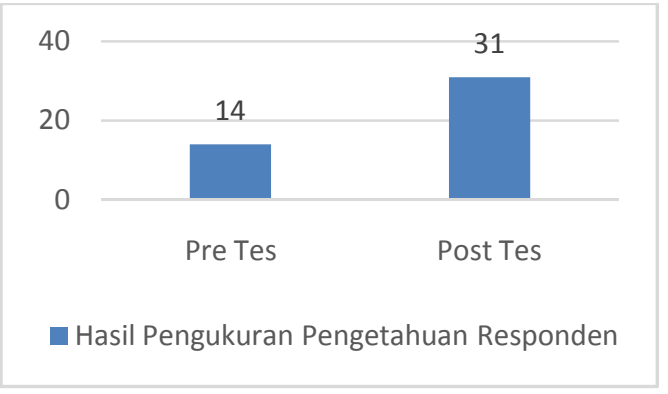

Seluruh ibu hamil berjumlah 31 orang hadir dalam pelaksanaan kegiatan pengabdian masyarakat ini, setelah diberikan kuesioner pre, didapatkan 14 peserta $(45,16 \%)$ dengan hasil kurang mengetahui bagaimana pelaksanaan ANC di masa pandemic ini, secara umum mereka takut dan cemas untuk melaksanakan ANC Karena takut akan terkena Covid- 19 ini, mereka menunda melakukan pemeriksaan padahal ANC ini penting sekali dilaksanakan untuk menjaga kesehatan dan kesejahteraan janinnya. Setelah diberikan 
penyuluhan dan penjelasan oleh narasumber, semua peserta31 $(100 \%)$ ibu hamil memahami pentingnya tetap melakukan ANC di masa pendemi dengan menjaga protokol kesehatan yang ketat.

\section{Gambar 3. Dokumentasi} Pengambilan Data

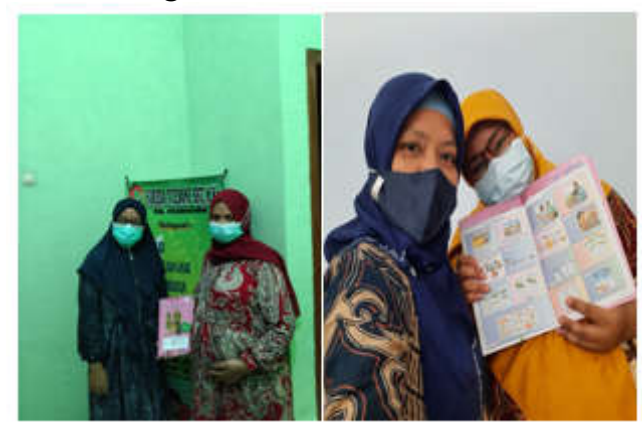

\section{Kesimpulan}

Kegiatan pengabdian masyarakat ini memberikan hasil yang positif bagi masyarakat terutama bagi ibu hamil, karena di masa pandemi ini ibu hamil harus tetap melakukan ANC secara rutin sesuai dengan jadwal agar ibu dan janinnya tetap sehat.

Hendaknya ibu hamil dan tenaga kesehatan tetap menjalankan protokol kesehatan yang ketat agar terlindung dan terhindar dari Covid 19 ini.

\section{Daftar Pustaka}

[1] E. S. Walyani, "Asuhan kebidanan pada kehamilan," 2015.

[2] H. Hendarwan, "Kualitas Pelayanan Pemeriksaan Antenatal oleh Bidan di Puskesmas," Bul. Penelit. Kesehat., vol. 46, no. 2, pp. 97-108, 2018.

[3] S. Notoatmodjo, "Ilmu perilaku kesehatan," 2010.

[4] M. Unas, "Webinar FIKES : Tenaga Kesehatan Punya Tantangan dan Peran Besar di Era New Normal,” 2020. https://www.unas.ac.id/berita/ webinar-fikes-tenaga.

[5] Kementerian Kesehatan RI, "Pedoman pelayanan antenatal, persalinan, nifas dan bayi baru lahir di Era Adaptasi Kebiasaan Baru.," Jakarta, 2020. 